ENTREPRENEURSHIP AND SUSTAINABILITY ISSUES

ISSN 2345-0282 (online) http://jssidoi.org/jesi/

2019 Volume 7 Number 2 (December)

http://doi.org/10.9770/jesi.2019.7.2(62)

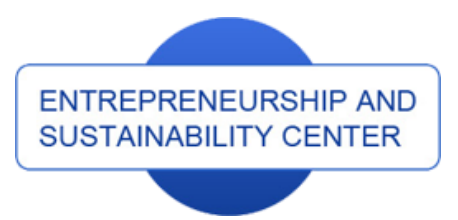

Publisher

http://jssidoi.org/esc/home

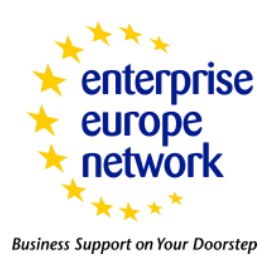

CASPA

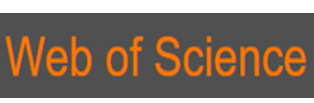

1) Clarivate

\title{
NAVIGATING ON THE KEY DRIVERS FOR A TRANSITION TO A GREEN ECONOMY: EVIDENCE FROM WOMEN ENTREPRENEURS IN SOUTH AFRICA*
}

\section{Eugine Tafadzwa Maziriri ${ }^{1}$, Miston Mapuranga ${ }^{2}$, Tafadzwa Clementine Maramura ${ }^{3}$, Ogochukwu I. Nzewi ${ }^{4}$}

\author{
${ }^{I}$ School of Economic and Business Sciences, University of the Free State, South Africa \\ ${ }^{2}$ The Da Vinci Institute for Technology Management, School of Managerial Leadership, Johannesburg, South Africa \\ ${ }_{3,4}^{3}$ Department of Administration, University of Fort Hare, South Africa
}

E-mails: ${ }^{1}$ maziririet@ufs.ac.za; ${ }^{2}$ mmapuranga@gmail.com $;{ }^{3}$ tmaramura@gmail.com $;{ }^{4}$ onzewi@ufh.ac.za

Received 17 February; accepted 26 November 2019; published 15 December 2019

\begin{abstract}
This research aims to determine how women entrepreneurs engaged in green entrepreneurship can help build a green economy in South Africa. The study was conducted using a non-probability conveniently selected sample of women green entrepreneurs operating in Gauteng Province, South Africa. A qualitative approach was followed involving semi-structured face to face interviews and focus groups with the selected participants. The collected data were analysed using thematic analysis. After the thematic analysis, four themes (drivers) for a Transition to a Green Economy emerged, which are green entrepreneurship education, the need for financial resources, green women entrepreneurs networking programmes and implementation for new green policies. The findings of the study will assist determine how women entrepreneurs work and engage in the green sector. Furthermore, this research makes a valuable contribution towards creating new knowledge in the green entrepreneurship sector by comprehending how women can help build a greener economy in South Africa.
\end{abstract}

Keywords: green entrepreneurship; women entrepreneurs; green economy

Reference to this paper should be made as follows: Maziriri, E.T., Mapuranga, M., Maramura, T.C., Nzewi, O.I. 2019. Navigating on the key drivers for a transition to a green economy: evidence from women entrepreneurs in South Africa. Entrepreneurship and Sustainability Issues, 7(2), 1686-1703. http://doi.org/10.9770/jesi.2019.7.2(62)

JEL Classifications: Q01, Q56, M00

\footnotetext{
* This research was supported by the Govan Mbeki Research Development Centre at the University of Fort Hare in South Africa.
} 


\section{ENTREPRENEURSHIP AND SUSTAINABILITY ISSUES}

ISSN 2345-0282 (online) http://jssidoi.org/jesi/

2019 Volume 7 Number 2 (December)

http://doi.org/10.9770/jesi.2019.7.2(62)

\section{Introduction}

Women have been looked down on for so long in the postmodern era, and because of this they are now growing in academic, economic, social, and business circles to alter the world around them (Shava, 2018). Similarly, in the past few decades, it was unimaginable for women to own businesses and successfully manage to run them in South Africa, however the present day state of affairs as confirmed by the World Bank (2017), shows that women entrepreneurs now account for a quarter to a third of all businesses in the formal economy worldwide. This confirmation points to the reality that women entrepreneurs are not simply redefining the role of women in the economic sphere, they are setting precedence by molding the contemporary overall economy. Women entrepreneurship is widely acknowledged as a precondition for sustainable economic growth and development in any country (Shava, 2018), however, very little is known about women entrepreneurial activities and the key drivers for transitioning to a green economy as enabling factors for including their business subsistence and growth strategies. According to Halvorsen (2015:1), "the concept of knowledge for viable democratic growth raises the question of how knowledge can contribute to the creation of an alternative political system that can replace what regulates, subjugates and exploits so much of the globe and its assets in the short-term interests of an insignificant minority, particularly women." For the Sustainable Development Goals (SDGs) discussions that arose from the UN's Post--2015 Development Agenda (UN 2013), accepting the transformation of the world economic system is essential (ICS / ISSC 2015; UN 2015). The problem of poverty that has paralyzed the entire world, particularly Africa, must be eradicated by providing imperative trade for all the economically active citizens of our planet, particularly females, through green entrepreneurship. Women are opening their own companies in record numbers in today's vibrant global economies, meaning women-owned companies are a noticeable proportion of all companies (Nxopo \& Iwu 2015). Chinomona and Maziriri (2015) also agree that females are increasingly turning to entrepreneurship as a manner to cope with the' glass ceiling,' which seems to stop them from achieving the highest levels of organizational management. Women have realized that in terms of company projects they can do what people do, or even better than others (Singh 2012). Mangin (2014) points out that females contribute to a country's green industry's increased accessibility of human resources by investing in their children's well-being and proper education. In addition, Roy (2012); Irene (2018) describe that women entrepreneurs are significantly contributing to environmental resource protection. There is a lot of attention paid to enpowernment of women (Yenilmez, 2018; Islam et al., 2018; Schouten, 2019; Kamasturyani et al., 2019; Fenech et al., 2019; Pinem, 2019). Furthermore, a major problem in South Africa is the lack of empirical studies on women entrepreneurs' contribution to the South African green economy and limited studies relating to the general profile of women green entrepreneurs in South Africa are available (IDC, 2017).

Women are progressively considered to play an important role in transforming nations with developing economies into a greener economy and reducing poverty (Mangin 2014). Hechavarria, Ingram, Justo and Terjesen (2014) point out that, compared to their masculine counterparts, females have greater environmental attitudes and are more likely to stress environmental issues. This is consistent with a research undertaken by Braun (2010) to determine whether women entrepreneurs may be more involved in green issues than their masculine counterparts. This is consistent with a research undertaken by Braun (2010) to determine whether women entrepreneurs may be more involved in green issues than their masculine counterparts. The research disclosed that female participants had greater environmental attitudes and dedication to green entrepreneurship than men, implying that female entrepreneurs may be more involved in green issues than masculine businessmen (Braun, 2010). In another current research that Ambepitiya (2016) undertook to explore the role of women entrepreneurs in developing countries in building sustainable development. The findings of the study showed that female entrepreneurs encourage green practices. More specifically, the research results examined that women entrepreneurs operate their companies in ways that minimize adverse environmental impacts and encourage green marketing, advertising and employment procedures (Ambepitiya 2016). Sumathi, Anuradha and Akash (2014) say that being a green business owner can provide significant, economically rewarding, socially accountable and 


\section{ENTREPRENEURSHIP AND SUSTAINABILITY ISSUES}

ISSN 2345-0282 (online) http://jssidoi.org/jesi/

2019 Volume 7 Number 2 (December)

http://doi.org/10.9770/jesi.2019.7.2(62)

environmentally useful jobs. At the same moment, it can assist females with their ambitious dedications to balance their family life (Sumathi, Anuradha \& Akash 2014). This paper will clearly highlight how research on women entrepreneurs in South Africa has tended to focus more on the informal sector while research on experiences and aspirations of South Africa's green economy has been relatively limited.

\section{Research questions}

The main research questions to emerge from the scope of the study are as follows:

- Can green entrepreneurship lead to a green economy?

- Can women entrepreneurs who are engaged in green entrepreneurship lead South Africa in the transformation to a greener economy?

- What opportunities and challenges emerge for women's participation in the green economy?

- Is the South African government supporting green entrepreneurial activity among women entrepreneurs?

\section{Problem statement and research gap}

Green entrepreneurship is viewed from a development view as an increasingly relevant trend; however, the literature survey indicates that it is still mainly under-researched (Ahmad, Halim, Ramayah, \& Rahman, 2015). Despite expanding research on entrepreneurship, O'Neill and Gibbs (2016) also point out that in-depth qualitative empirical research with green entrepreneurs has been restricted to date, concentrating instead on typologies that categorize certain' kinds' of green entrepreneurs. Previous research in South Africa has examined female entrepreneurs in different situations by concentrating on the problems faced by women entrepreneurs in the Gauteng province of South Africa (Chinomona \& Maziriri 2015). In addition, Mandipaka (2014) focused on an overview of women entrepreneurs in South Africa. Furthermore, the barriers that hinder the success of women entrepreneurs in Gauteng, South Africa were investigated by Khalwaya and Havenga (2012). Additionally, Chiloane and Mayhew (2010) determined the difficulties experienced by black women entrepreneurs in accessing instruction from the South African Small Business Development Agency. Moreover, Meyer (2009) investigated the determinants of women's entrepreneurship. Against this background, there is a lacuna in studies that are centred on women who are engaged in green entrepreneurship and hence, the fundamental motivation behind this investigation is to fill this gap.

\section{Significance of the Study}

The research investigated a present-day significant and topical development problems not only for developing nations but all over the globe, namely moving towards a green economy through the implementation of green entrepreneurship among women entrepreneurs. Promoting women's entrepreneurship in green or organic cooperatives is a comparatively fresh idea that continues to evolve in practice when coupled with marketing and abilities development training, it has the potential to foster women's entrepreneurship, women's revenue generation and women's empowerment as well as help them reduce poverty (Sanyang \& Huang 2008). Akpunonu and Muogbo (2015) opined that investing in women is recognized not only as the right thing to do but also the smart thing to do. Therefore, the knowledge generated by this study is useful not only to South Africa, but also to other developing countries in the area of women entrepreneurship and green entrepreneurship.

\section{Overview of the Gauteng Province}

This paper aims to gather information that can be applied in the development of women who are engaged in green entrepreneurship within the Gauteng province of South Africa. Figure 1 presents a geographical map of the Gauteng province of South Africa. 


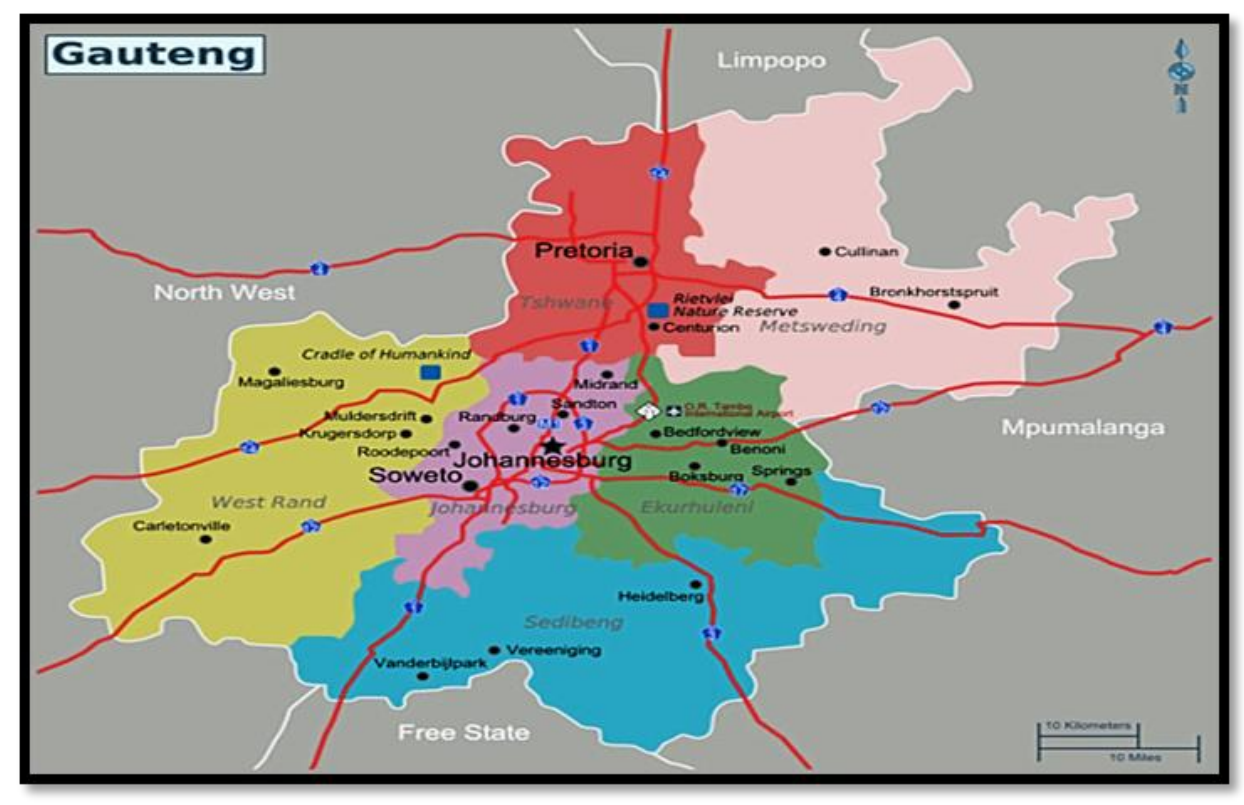

Figure 1. Map of Gauteng Province of South Africa

Source: http://www.south-africa-tours-and-travel.com/map-of-johannesburg-south-africa.html

South Africa's Gauteng province is in the country's north-central portion (Senatla 2011). According to Meyer (2009), the Gauteng Province is South Africa's biggest financial sub-region: it accounts for 19.7 percent of the country's total population and about 40 percent of the national product. Chinomona and Maziriri (2015) point out that Gauteng is not just South Africa's economic hub, which makes a major contribution to the financial, production, transportation, technology and telecommunications industries. It also hosts, more than any other country on the continent, many overseas companies requiring a commercial base in, and gateway to, Africa.

Knight, Harland, Telgen, Thai, Callender and McKen (2012) explain that Gauteng is South Africa's smallest province with a $21,025 \mathrm{~km}$ region. Although Gauteng is only $1.7 \%$ of South Africa's total region, $18.5 \%$ of South Africa's total population resides in the province (Knight, Harland, Telgen, Thai, Callender \& McKen 2012). Jogee and Callaghan (2014) believe that Gauteng, with the largest urbanization rate, is the most populous province. Gauteng's Green Strategic Program (2011) points out that Gauteng is South Africa's financial engine, and subSaharan Africa, the province may be economically rich, but it is poor in terms of water, air and soil. Moreover, Gauteng is also beginning to feel the rebound effects of previous outsourcing of unsustainable development expenditures, such as polluting mining activities, which will affect the province's economic competitiveness and job creation potential (Gauteng's Green Strategic Program, 2011).

\section{Literature Review}

Literature review plays a key role in the ongoing studies. Efforts are aimed in this chapter to investigate or evaluate the results of the research undertaken in the same field by different academics. Furthermore, this chapter is based on a literature review of all appropriate materials including study studies, articles, case studies, surveys and project reports released by UN agencies, international organizations and academic problems related to female entrepreneurs, the role of female entrepreneurship in South Africa's financial development, green entrepreneurship and the green economy. Also collected and studied were national reports, policies, strategies and future plans concerning women entrepreneurs. 


\section{ENTREPRENEURSHIP AND SUSTAINABILITY ISSUES}

ISSN 2345-0282 (online) http://jssidoi.org/jesi/

2019 Volume 7 Number 2 (December)

http://doi.org/10.9770/jesi.2019.7.2(62)

\section{Theoretical grounding}

This research takes as its theoretical framework the concept of ecological modernization. This is because the theory of ecological modernization can be deemed critical to the development of green entrepreneurial projects by women entrepreneurs in South Africa's Gauteng province.

\subsection{Ecological Modernization Theory}

The theory of ecological modernization (EMT) suggests that continued industrial development, rather than inevitably continuing to degrade the environment, is the best way to escape the global environmental challenge (York \& Rosa 2003). The environmental issues facing the world today function as a driving force for future industrial activity and economic development (Murphy 2000), according to the Ecological Modernization Theorists. McEwen (2013) says that with the concept of ecological modernization, financial growth can be encouraged by providing the environment a greater priority. Furthermore, EMT's father Joseph Huber (Mol 1995) emphasizes that entrepreneurs are the key agents of change in the transformation process in order to prevent an ecological crisis (Gibbs 2009; Mol \& Spaargaren 1993; Tillery \& Young 2009). It can be observed that EMT talks about capitalizing on the setting without harming it based on the explanations of the authors. Furthermore, if consideration is given to the EMT, it may improve the growth of women entrepreneurs involved in green entrepreneurship.

\subsection{Women Entrepreneurs}

While growing numbers of females are becoming leaders of their own companies, shedding light on what it entails to be a woman entrepreneur is essential. Chinomona and Maziriri (2015) describe a female entrepreneur as a female who plays a captivating role by interacting and adapting herself constantly with fields of economic, socioeconomic and social assistance. Maheshwari and Sodani (2015) also agree that a female entrepreneur is an individual who accepts a difficult position in meeting their private requirements and becoming economically autonomous. According to Manerkar (2015), women entrepreneurs can be well-defined as females or a group of females initiating, organizing and running a company. Women entrepreneurs are those who have started and have been actively engaged in managing companies; own at least 50 percent of the company and have been in service for a year or longer (Xavier, Ahmad, Nor \& Yusof 2012).

\subsection{The Role of Women Entrepreneurship in the Economic Development of South Africa}

The key to unlocking economic growth is South African women entrepreneurs. Women constitute 52\% of the total population in South Africa, and several surveys demonstrate that more females have been engaged in entrepreneurship since independence was achieved in 1994 (Deborah, Wilhelmina, Oyelana, \& Ibrahim 2015). Akhalwaya and Havenga (2012) point out that the most significant assets of any nation are those of human capital and since females make up more than half of South Africa's inhabitants, they are the one resource that needs to be brought to the mainstream of the economy. Chinomona and Maziriri (2015) explain that women entrepreneurs from South Africa are engaged in survival processes such as sewing cooperatives, chicken farming, candle making, gardening, and arts and crafts. According to Akhalwaya and Havenga (2012), their business contribution is mainly in the fields of craft, hawking, personal services and retail. Furthermore, the role of a female entrepreneur is obvious in the growth of leadership, management, innovation, efficiency of research and development, job creation, competitiveness, productivity, and the formation of new sectors (Nxopo 2014). Van der Merwe (2008) argues that female entrepreneurship is growing quickly and that females are growing and starting their own business to take control of their personal and professional lives. Nxopo (2014) stressed that the role of these female entrepreneurs in eradicating poverty and unemployment in South Africa cannot be underestimated and research on the contribution and growth of female entrepreneurs at all levels of the South African economy is needed. Meyer (2009) points out that women entrepreneurs are increasingly seen as important to economic development and contribute not only to job creation, but also to the diversity of entrepreneurship in the economic process. In addition, it can be observed from the author's explanations that female entrepreneurs 


\section{ENTREPRENEURSHIP AND SUSTAINABILITY ISSUES}

ISSN 2345-0282 (online) http://jssidoi.org/jesi/ 2019 Volume 7 Number 2 (December) http://doi.org/10.9770/jesi.2019.7.2(62)

have become significant players in the entrepreneurial landscape by making contributions to business development in South Africa.

\subsection{The Green Economy}

Hassan and Nordin (2016) explain that the main focus of the green economy is on the junction between the location and the economy. According to the United Nations Environment Program (UNEP), (2011) a green economy is viewed as a system of economic activity that includes the production, consumption and distribution of goods and services to enhance the quality of life of people. The Green Economy notion is also defined as an economy in which economic growth and environmental responsibility operate together in a mutually reinforcing fashion while promoting progress on social development, enhancing human well-being and social equity at the same time (Creech, Huppé, Paas \& Voora, 2012). As a result, one of the green economy's most important goals is to avoid future generations from significant environmental hazards and economic scarcity (UN Environment Program, 2011). Greening the economy in South Africa is particularly important for two fundamental reasons: (1) the country's exceptional level of unemployment and (2) the economy's high carbon impact (Borel-Saladin \& Turok 2013). Furthermore, according to the International Labor Organization (ILO) (2016), the South African government views a green economy as a sustainable development route, based on addressing the interdependence between economic growth, social protection and natural ecosystems, and has a number of substantial projects underway to promote the Sustainable Development Goals (SDGs) in the field of sustainable development. In addition, Uslu, Demir and Hancioglu (2015) explain that the advantages and disadvantages of a green economy transition on their paper. These are indicated in Table 1.

Table 1. The advantages and disadvantages that may arise during and after the transition to green economy

\begin{tabular}{|c|c|}
\hline Advantages & Disadvantages \\
\hline $\begin{array}{l}\text { Developing of new production options: new products } \\
\text { having new functions suited to maximize the utilization } \\
\text { rate and value, new processes and forms of industrial } \\
\text { symbiosis able to achieve higher and higher levels of } \\
\text { global performance and to continuously reduce the unit } \\
\text { incidence of the amount and cost for energy and materials } \\
\text { in the whole production cycle and, at the same time, the } \\
\text { amount of emissions and wastes. }\end{array}$ & $\begin{array}{l}\text { High prices for energy and mineral resources. High prices } \\
\text { for agro-food and agro-industrial resources. }\end{array}$ \\
\hline $\begin{array}{l}\text { Development and maturation of new technologies in all } \\
\text { fields of activity, giving rise to a wide range of equivalent } \\
\text { solutions able to satisfy more appropriately the local and } \\
\text { global needs and aims (foodstuffs included). }\end{array}$ & $\begin{array}{l}\text { High investment costs for the development of new } \\
\text { technologies in all fields (for research, in all forms, and at } \\
\text { all levels). }\end{array}$ \\
\hline $\begin{array}{l}\text { Easy, eco-compatible and economic end of life of goods } \\
\text { (disassembling, recovering, recycling). }\end{array}$ & $\begin{array}{l}\text { Production cost and market price increases of durable } \\
\text { goods, having sustainable features (functions to increase } \\
\text { their use intensity and durability). Deep modification of the } \\
\text { hierarchy of goods and in branches of activity (industry } \\
\text { and service sector). }\end{array}$ \\
\hline $\begin{array}{l}\text { Improvement of enterprises competitiveness through the } \\
\text { qualification achieved with adoption of sustainable } \\
\text { management criteria. Birth and increases of small to } \\
\text { medium sized service and technical assistance firms and } \\
\text { new employment creation. Assumption by enterprises, } \\
\text { singly and as a system of social responsibility in a way to } \\
\text { increase their competitiveness and contribute to spread the } \\
\text { culture of resource conversation as a reference point in all } \\
\text { choices }\end{array}$ & $\begin{array}{l}\text { Reduction of produced volumes by enterprises and of their } \\
\text { mission, nature, size and relations. Increased } \\
\text { unemployment levels (mainly from large industries). }\end{array}$ \\
\hline $\begin{array}{l}\text { Increase overall resources productivity and reduce the } \\
\text { demand for energy and other natural resources }\end{array}$ & $\begin{array}{l}\text { Probable decrease of global and per-capita wealth (GNP) } \\
\text { in industrialized countries. Reduction of average buying } \\
\text { power of families. }\end{array}$ \\
\hline
\end{tabular}


ENTREPRENEURSHIP AND SUSTAINABILITY ISSUES

ISSN 2345-0282 (online) http://jssidoi.org/jesi/

2019 Volume 7 Number 2 (December)

http://doi.org/10.9770/jesi.2019.7.2(62)

\begin{tabular}{|l|l|}
\hline Restoration of original environmental balances & $\begin{array}{l}\text { Enormous costs for transforming cities and metropolitan } \\
\text { areas to achieve sustainable living and working places. }\end{array}$ \\
\hline $\begin{array}{l}\text { Redistribution of wealth between industrialized and non- } \\
\text { industrialized countries (if the latter start appropriate } \\
\text { development phase). }\end{array}$ & $\begin{array}{l}\text { Enormous investment costs to invent and produce new } \\
\text { transportation and accessibility systems that are low } \\
\text { material intensive, energy efficient, fast and safe, } \\
\text { ecologically sound and economically advantageous. }\end{array}$ \\
\hline $\begin{array}{l}\text { Great improvement of the quality of life in the sustainable } \\
\text { cities starting from the quality of air, water, living } \\
\text { standards, quality and safety of mobility. }\end{array}$ & $\begin{array}{l}\text { Reduction of mobility time to work and for other personal } \\
\text { needs, reduction of transportation costs, increased resource } \\
\text { productivity, reduction of pollution connected to new } \\
\text { material and energy-intensive, long-life transportation } \\
\text { means and increase in safety }\end{array}$ \\
\hline \multicolumn{2}{|l|}{ Source: Ulu, Hancioglu and Demir $(2015: 124)$} \\
\hline
\end{tabular}

\subsection{Green entrepreneurship}

Green entrepreneurship is lauded as one of the main mechanisms to leverage in making the step towards the green economy (Ahmad, Halim, Rahman \& Ramayah 2015:91). Pastakia (1998) earlier defined green entrepreneurship as an effort by entrepreneurship to propagate environmentally friendly practices by market or non-market methods. Kotchen (2009) indicates that green entrepreneurship can be characterized as the practice of starting up new companies in reaction to a recognized chance to gain a profit and provide (minimize) beneficial (adverse) environmental externality. Pachaly (2012) defines green entrepreneurship as entrepreneurs using open space business tools, develop wildlife habitat, save endangered species and generally improve environmental quality. Moreover, the "green" entrepreneurship is an economic activity whose products, services, methods of production or organization have positive effect on the environment (Gevrenova 2015).

\section{Methodology and Design}

The research design that was adopted for this study was essentially exploratory in nature. The exploratory approach, in this case, was expected to provide the opportunity to unravel the views of green women entrepreneurs pertaining to green entrepreneurship and its ability to lead them towards a green economy. The rationale for using exploratory research was to obtain a richer understanding of green entrepreneurship in the pursuance of their businesses. Essentially, and in keeping with the approach stated above, during the interview, participants were given the opportunity to describe their views of green women entrepreneurs pertaining to green entrepreneurship and its ability to lead them towards a green economy. The researchers adopted a qualitative approach that was exploratory in nature. The reason for adopting qualitative methodology was the need to understand the experiences of women green business owners. Chinomona et al. (2014) point out that in a qualitative research, the researcher builds a complex, holistic picture; analyses words; reports detailed views of informants; and conducts the study in a natural setting. In addition, Xaba and Rankhumise (2014:184) noted that 'the qualitative research method is appropriate when the researcher is trying to understand a new phenomenon in a particular situation rather than trying to establish a relationship between two or more variables.

\subsection{Research paradigm}

A research paradigm refers to a set of philosophical assumptions and beliefs that directs the research (Jonker \& Pennink 2010). According to Wahyuni (2012) research is commonly divided into four paradigms which are positivism, post-positivism, interpretivism, and pragmatism. This study subscribes to the interpretive paradigm. According to Thanh and Thanh (2015) interpretivism usually seeks to understand a context, and the core belief of the interpretive paradigm is that reality is socially constructed. Creswell (2009) clarifies that interpretive methodology is directed at understanding phenomena from an individual's perspective, investigating interaction among individuals as well as the historical and cultural contexts which people inhabit. Interpretivists believe an 


\section{ENTREPRENEURSHIP AND SUSTAINABILITY ISSUES}

ISSN 2345-0282 (online) http://jssidoi.org/jesi/

2019 Volume 7 Number 2 (December)

http://doi.org/10.9770/jesi.2019.7.2(62)

understanding of the context in which any form of research is conducted is critical to the interpretation of data gathered (Thanh \& Thanh, 2015).

\subsection{Unit of analysis}

A unit of analysis is defined as the main body that is being analysed in a study (Antonites \& Kliphuis 2011). In this study, the unit of analysis is the South African green women entrepreneurs residing in the Gauteng province of South Africa.

\subsection{Population of the study}

In research, population refers to the aggregate of all the units that are eligible to participate in a study (Creswell \& Plano, 2007:112; Salkind, 2012:95). In addition, Welman, Kruger and Mitchell (2011:53) defined population is as a group of entities with a common set of characteristics. In this study, the population of relevance will consist of all green women entrepreneur living within the Gauteng province of South Africa.

\subsection{Sample size}

A sample can be defined as a portion of a larger population (Dube, Roberts-Lombard \& Van Tonder, 2015:243). Roets (2013:36) defines sample size as the count of factors involved in the study. A sample size larger than 30 and less than 500 is appropriate for most research studies (Xaba \& Rankhumise, 2014; Choto et al., 2014:97). Therefore, this research study utilized 35 participants.

\subsection{Sampling technique}

Dahlberg and Mccaig (2010:175) assert that two methods exeunt for sampling, namely probability and nonprobability sampling. As there was no register of women green entrepreneurs, convenience sampling method was used to select the respondents. The respondents were chosen for providing inside information about green entrepreneurship.

\subsection{Face-to-face interviews}

Interviews provide an avenue for generating data by talking to people about how they go about their day-by day dealings (Thompson, Bounds, \& Goldman, 2012:40). The researcher managed to conduct the interviews while at the same time recording the interviews and taking short notes for future coding. The general observation was that each interview would trigger the necessity for another interview as the themes began to unfold. The convergent in-depth interviewing used in this study allowed the researcher to develop, clarify, verify and refine the core issues of the interview protocol. During the early stages, the content of the interview was unstructured and flexible to allow the interviewees to communicate freely their experiences and considered views concerning the green entrepreneurship and its ability to lead them towards a green economy. The process used in the interview became more structured as the interviewer converged in specific issues of the research problem and sought further clarifications on certain issues. Finally, after conducting a total of fifteen (15) interviews the researcher felt it was enough but needed to further corroborate the findings with the data from five more informal conversations. During the informal conversations, field notes were also taken, and memos developed thereafter. Unlike in quantitative research, qualitative research views literature review as an ongoing process and serve as a source of data (Wilson, 2010). As put forward by Wilson (2010), literature from documented material should be viewed equally the same as field notes. The same point was buttressed by Bryman (2004) who referred to documented literature as "everything is data" and Cooper and Schindler (2011) who asserted that a "cache of archival material" is equivalent to a collection of interviews and field notes. These documents served two purposes. Firstly, they were treated as another source of data collection. Secondly, as noted by Enslin (2001), prior reading provided models to help the researcher make sense of the data gathered on SDGs and green entrepreneurship and probe further the interviewees where necessary. 


\section{ENTREPRENEURSHIP AND SUSTAINABILITY ISSUES}

ISSN 2345-0282 (online) http://jssidoi.org/jesi/

2019 Volume 7 Number 2 (December)

http://doi.org/10.9770/jesi.2019.7.2(62)

\subsection{Focus group}

A focus group of six female entrepreneurs was performed in the research. These women entrepreneurs classified themselves as green women entrepreneurs because they focus on green entrepreneurship in their businesses. For instance, selling energy-efficient lighting, having an environmentally friendly beauty salon, viable farming, and manufacturing as well as selling environmentally friendly soap. Focus group is a form of quantitative research in which a group of people are asked questions about their opinions, perceptions, beliefs and attitudes towards a product, service, concept or idea (Wilson, 2010). Bryman (2004) and Cooper and Schindler (2011) defined a focus group as an interview conducted by a trained interviewer among a small group of respondents. Questions are asked in an interactive group setting where participants are free to give views from any aspect and talk with each other. Focus group allows interviewers to study people in a more natural conversation pattern than typically occurring in a one to one interview. Fairly low cost compared to surveys, as one gets results relatively quickly and increase the sample size of a report by talking to several people at once. However, there is the disadvantage of observer dependency raising questions of validity unless the interviewing of the focus group is repeated several times (Zikmund, Babin, Carr \& Griffin, 2010). The next section focuses on a comprehensive discussion of the findings.

\section{Data analysis}

All interviews were documented and transcribed for analysis. The study employed a qualitative research design using thematic analysis. The Grounded Theory technique is a systematic approach encompassing the discovery of theory through the analysis of data. After verbatim transcription of the face-to-face interviews and focus group interviews, the researchers analyzed all the records of the interviews by using the process suggested by Corbin and Strauss (1990). The researchers recommended the utilization of the following procedures in the data analysis: Open coding: According to Corbin and Strauss (1990:4) "open coding is the process of breaking down, examining, comparing, conceptualizing and categorizing data". The researchers began data analysis by interpreting the recorded notes and paying attention to the interviews documented on tape to familiarize themselves with the data. This stage was important to ensure that the researchers captures all the important points raised by respondents in the focus group interviews and to establish the depth of the data.

Axial coding: According to Madinga and Maziriri (2018), axial coding involves reading the transcribed notes again to identify the connections between the themes that emerged from open coding. The researchers reviewed the themes to analyses the relationship between themes and sub-themes. Themes that were related, were further collapsed to come up with one dominant theme.

Selecting coding: "selective coding is the procedure of selecting the core category, systematically relating it to other categories, validating those relationships, and filling in categories that need further refinement and development" (Corbin and Strauss 1990:5). This procedure was undertaken to identify the main themes that were related to the study (Cresswell 2014), and draw conclusions grounded on the emerged themes.

\section{Findings}

The main findings obtained from the focus group and the transcripts of the interviews were green entrepreneurship education, the need for financial resources, the need for networking events among green entrepreneurs and the need to implement for new green policies. These results are described as topics emerging from a method called thematic analysis in the following parts (9.1 to 9.4). Thematic analysis is defined as "a meticulous process of identifying, analysing and reporting themes that emerge from a qualitative study" (Mupohi, 2015:168; Muposhi, Dhurup \& Surujlal, 2015:230; Retief, 2009:42; Braun \& Clarke, 2006:79). Thematic analysis is considered the "fundamental method of qualitative analysis" and was chosen to formally trade the analytical process due to its suitability to the exploratory character of the research (Apolloni, 2010:88). "The main advantage of the thematic analysis is that it is a logical process which allows the researcher to scrutinize interview transcripts comprehensively and glean all possible themes"' (Muposhi, 2015:168; Muposhi, Dhurup \& Surujlal, 


\section{ENTREPRENEURSHIP AND SUSTAINABILITY ISSUES}

ISSN 2345-0282 (online) http://jssidoi.org/jesi/

2019 Volume 7 Number 2 (December)

http://doi.org/10.9770/jesi.2019.7.2(62)

2015:230; Glesne, 2011:187). The following framework indicates the main themes identified in the data sources. Each theme will be discussed individually, followed by substantiating quotes. Interpreted data will be compared with existing literature.

\subsection{Theme 1-Green entrepreneurship education}

Green entrepreneurship education emerged during interviews as one of the most important topics. The green women businessmen have stated a need for green education. Furthermore, the respondents (green women entrepreneurs) stated that training entrepreneurs about green entrepreneurship is essential for universities and other tertiary education organizations. Here are some of their comments:

"Although I am a green entrepreneur, I wish to obtain more knowledge of green entrepreneurship from universities as the issue of going green is topical in today's postmodern era" [Thandeka, Seller of Energy Efficient Lighting]

"As women, if we are to be thought about the benefits of green entrepreneurship, we can be at the forefront of motivating the entire nation to transit to a green economy" [Charlotte, Green Florist]

\subsection{Theme 2- The Need for Financial resources}

Another theme that emerged from interviews was the need for financial resources. Most of the participants attested that there is need for the government to allocate more financial resources to women entrepreneurs especially those are still at the introductory stage of green entrepreneurship. This was reflected by the following statement:

"There are some machineries that I would need to have in my eco-friendly beauty salon, but I can't acquire them all because there are expensive. I wish if the government would recognise us as green entrepreneurs in terms of financial support" [Jenny, Eco-Friendly Beauty Salon owner]

\subsection{Theme 3- Green women entrepreneurs networking programmes}

Green women entrepreneurs networking programmes appear to be one of the dominant themes that emerged from interviews. The study's theme encompasses a socioeconomic green business activity by which green women entrepreneurs meet to form business relationships and to recognize, create, or act upon business opportunities, share information and seek potential partners for green ventures. The participants expressed themselves as follows:

"For South Africa to end up being a green economy it is imperative to have networking programmes centred on green business issues" [Hope, Green Fair Organizer]

"With networking programmes, I believe we will be able to share green business ideas as well as to make partnerships with other green entrepreneurs, this will ultimately assist South Africa to transform into a green economy" [Samantha, Eco-Friendly Toy Seller]

\subsection{Theme 4: Implementation for new green policies}

"I personally feel that, although there is the South African Environmental Act, other environmental policies should be drafted and come into effect so as to have strict measures of developing our country towards a green economy" [Eco-Friendly Soap Maker]

"It would be imperative for the government to introduce some penalties to those who harm the environment which we live when conducting their business operations. It might be harsh but after negative reinforcement works" [Pamela, Sustainable Farmer]

\section{Conceptual Model}

After thematic analysis of research data, a conceptual model was developed. Below is an illustration of the research conceptual model. Above is an illustration of the research conceptual model of the current study. After analysis of themes observed in the study, it was found that green entrepreneurship education, the need for 
financial resources, green women entrepreneurs networking programs and implementation for new green policies be categorized as key drivers for a transition to a green economy among women green entrepreneurs in the Gauteng province of South Africa.

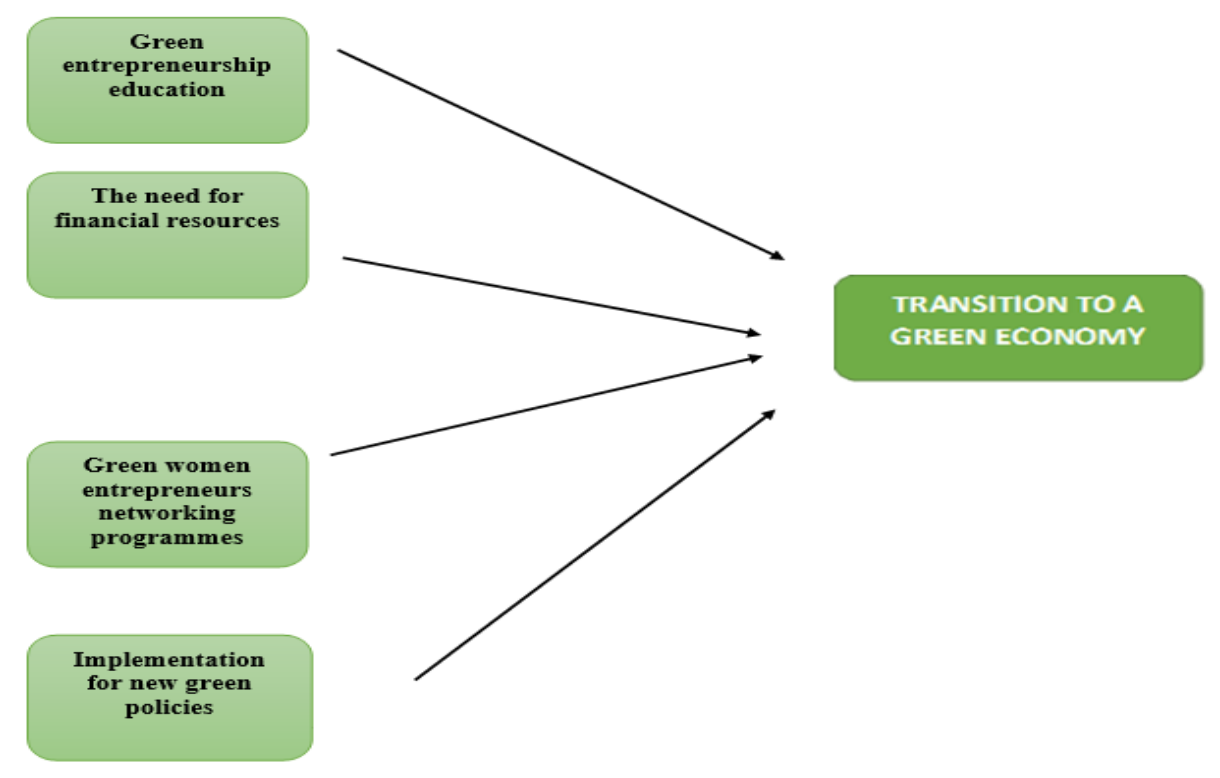

\section{Recommendations}

Especially among black women, a spirit of green entrepreneurship needs to be instilled in the Gauteng province because efficiency and effectiveness are still below the level needed. Since the remnants of its apartheid regime, South Africa is one of the poorest countries in Africa (Meyer \& Hofmeyer 1995; Enslin 2001; Soudien 2004). Much requires to be done to have effective and efficient education that results in worldwide competitiveness and green entrepreneurship for companies. To be of high quality, up to standard and applicable to the recipients, our green entrepreneurship thinking still needs to be improved. In terms of gloomy entrepreneurs, universities alone cannot make the change on their own, it requires participatory approach from all angles. This will efficiently and effectively create the conversion. It does not result in any criticism from other areas of society as there will be space for everyone to be involved. Although a participatory strategy is so laborious, and it takes too long to transform greater learning institutions and thus improve entrepreneurship (Radebe 2013). Therefore, much requires to be done to change teaching methods and go for green entrepreneurship.

Government needs to allocate more financial resources to women entrepreneurs, particularly those still in the introductory phase. All South African greater education organizations need to alter curricula and concentrate more on green entrepreneurship. For its students, the quality of learning and teaching and the shift from a teachercentred approach to a more learner-centred approach means putting the needs of the learner at the heart of activities (Chinomona et al., 2013). It is also essential to note that some of these learners are not empty vessels. They should be allowed to make their own decisions and learn on their own concerning green entrepreneurship. 


\section{ENTREPRENEURSHIP AND SUSTAINABILITY ISSUES}

ISSN 2345-0282 (online) http://jssidoi.org/jesi/

2019 Volume 7 Number 2 (December)

http://doi.org/10.9770/jesi.2019.7.2(62)

\section{Implications of the study}

The present study is an effort to conduct research in a context that is often most ignored but is significant in the South African business industry. Consequently, the results of this empirical research are anticipated to have to provide fruitful consequences across all stakeholders in tertiary schools in South Africa to put more emphasis on green entrepreneurship as it gives money to government, offers jobs and poverty alleviation. All individuals need to be engaged in decision making for the efficacy to be realized, including the parents. Therefore, this research argues that educational leadership formulating strategies that lead to high-quality education makes higher learning institutions pleasant areas to work for and be appreciated. In the manner they do their stuff, top management will learn and alter for the better and concentrate more on green entrepreneurship as it gives more money to the state and the individuals involved. But much is required to realize this dream of green entrepreneurship by contributing appropriate funds.

In order to contribute to the SDGs, knowledge generation on green entrepreneurship must be secure in their independence and work in universities with academic autonomy. Acceptance that the opportunities for these institutions to massively increase their income streams in the near future are slim. Thus, affordable incentive schemes that have the potential to reward academics and encourage independent research will help a great deal in terms of green entrepreneurship. A number of the 17 SDGs are relevant to the issue of a new global political economy and Objective 8, in this respect (promoting sustainable, inclusive and sustainable economic growth, complete and productive jobs and decent work for all) is often quoted as particularly appropriate. Discussions on the SDGs so far indicate a high amount of consciousness that racism and other types of prejudice have the potential to undermine any alternatives to the worldwide environmental problems facing humanity, as well as the need to ensure the fundamental right of every individual to an honourable life.

\section{Limitations and Future research}

Despite this study's contribution, it has its constraints that provide opportunities for future research, since this current study only focused on the province of Gauteng. Perhaps if the collection of data is extended to include other provinces such as the Eastern Cape, Free State, KwaZulu-Natal, Limpopo, Mpumalanga, Northern Cape and North West, the results may be more insightful. Therefore, future studies should consider this recommended direction of research. Furthermore, the information gathered are based on only women entrepreneurs' reactions. While women may be the top green entrepreneurs, there are males involved in green entrepreneurship, and their contribution to putting South Africa forward towards a green economy is also of paramount significance. Perhaps above all, insightful findings can be produced if men entrepreneurs are to be interviewed. There is also the issue of common method bias due to the pure use of qualitative research in this study. It was going to be more robust if the study included both qualitative and quantitative methods. All in all, these suggested future avenues of study stand to immensely contribute new knowledge to the existing body of green entrepreneurship literature, a context that happen to be less researched by some researchers in Africa.

\section{Conclusion}

In summation, extensive literature review was conducted in this study to spawn an overview or to gain a depth understanding of green entrepreneurship. This study offers a comprehensive analysis of the key drivers that are necessary in transitioning towards a green economy in the context of South African female entrepreneurs. This study further provides a basis for an agenda for enhanced focus on training and development of the entrepreneurial competencies of female green entrepreneurs in South Africa. On the academic side, this study makes a significant contribution to the green entrepreneurship literature by systematically exploring the impact of green entrepreneurship, efficiency and effectiveness in the context of women entrepreneurs in the Gauteng province. 


\section{ENTREPRENEURSHIP AND SUSTAINABILITY ISSUES}

ISSN 2345-0282 (online) http://jssidoi.org/jesi/

2019 Volume 7 Number 2 (December)

http://doi.org/10.9770/jesi.2019.7.2(62)

\section{References}

Ahmad, N.H., Halim, H.A., Rahman, S.A. and Ramayah, T., 2015. Green entrepreneurship proclivity among Generation Y nascent entrepreneurs of Malaysia. In Economics, Social Sciences and Information Management: Proceedings of the 2015 International Congress on Economics, Social Sciences and Information Management (ICESSIM 2015), 28-29 March 2015, Bali, Indonesia (p. 91). CRC Press.

Ahmad, N.H., Halim, H.A., Ramayah, T. \& Rahman, S.A., 2015. Green entrepreneurship inclination among Generation Y: the road towards a green economy. Problems and Perspectives in Management, 13(2), 211-218.

Akhalwaya, A. \& Havenga, W., 2012. The barriers that hinder the success of women entrepreneurs in Gauteng, South Africa. OIDA International Journal of Sustainable Development, 3(5), 11-28.

Akpunonu, U.E. \& Muogbo, U.S. 2015. Women entrepreneurship as an inventive approach to ensure a sustainable development in developing economies. International Journal of Emerging Technology and Advanced Engineering, 5(1), 36-41.

Ambepitiya, K.R. 2016. The role of women entrepreneurs in establishing sustainable development in developing nations. World Review of Business Research, 6(1), 161-178.

Antonites, A. \& Kliphuis, W. 2011. An exploratory study on the potential value adds of social networking to the entrepreneurial process. The Southern African Journal of Entrepreneurship and Small Business Management, 4(1), 1-23.

Apolloni, L. 2010. Bringing about behavior change: nursing practice and cardiac rehabilitation. Doctor of Public Health thesis, University of Wollongong. School of Health Sciences, University of Wollongong. Wollongong, New South Wales.

Boral-Saladin JM \& Turok IN. 2013. The impact of the green economy on jobs in South Africa. South African Journal of Science, 9(10), 14.

Braun, P. 2010. "Going green: women entrepreneurs and the environment", International Journal of Gender and Entrepreneurship, 2(3), 245-259.

Braun, V. \& Clarke, V. 2006. Using thematic analysis in psychology. Qualitative Research in Psychology 3, 77-101

Chiloane, G.E. \& Mayhew, W. 2010. Difficulties encountered by black women entrepreneurs in accessing training from the small enterprise developing agency in South Africa. Gender and Behavior, 8(1), 2590-2602.

Chinomona, E. \& Maziriri, E.T., 2015. Women in Action: Challenges Facing Women Entrepreneurs in the Gauteng Province of South Africa. The International Business \& Economics Research Journal, 14(6), 835-850.

Chinomona, E. Maziriri, E. \& Moloi, K.C. 2013. Corporate Entrepreneurship with Innovation in Mind in one University of Technology in South Africa. Mediterranean Journal of Social Sciences, 5(23), 20-29.

Choto, P., Tengeh, R. K. \& Iwu, C. G. 2014. Daring to survive or to grow? The growth aspirations and challenges of survivalist entrepreneurs in South Africa. Environmental Economics, 5(4), 93-101.

Cooper, D.R. \& Schindler P.S. 2011. Business Research methods. $11^{\text {th }}$ ed. Singapore: McGraw- Hill.

Corbin, J. M., \& Strauss, A. 1990. Grounded theory research: Procedures, canons, and evaluative criteria. Qualitative sociology, 13(1), 321.

Creech H, Huppé GA, Paas L \& Voora V. 2012. Social and environmental enterprises in the Green Economy: supporting sustainable development and poverty eradication on the ground. Analysis of a 3-year study for policy makers. SEED Initiative, International Institute for Sustainable Development. P.7

Cresswell, T. 2014. Place: an introduction. John Wiley \& Sons. 


\section{ENTREPRENEURSHIP AND SUSTAINABILITY ISSUES}

ISSN 2345-0282 (online) http://jssidoi.org/jesi/

2019 Volume 7 Number 2 (December)

http://doi.org/10.9770/jesi.2019.7.2(62)

Creswell, J. W. \& Plano, C. V. L. 2007. Designing and conducting mixed methods research, Sage, Thousand Oaks, CA.

Dahlberg, L., \& McCaig, C. 2010. Introduction to research and evaluation basics. Practical Research and Evaluation: A Start-to-Finish Guide for Practitioners, SAGE, London, 13-28.

Deborah, A.E., Wilhelmina, S., Oyelana, A.A. and Ibrahim, S.I., 2015. Challenges Faced by Women Entrepreneurs and Strategies Adopted by Women Entrepreneurs to Ensure Small Business Success in Nkonkobe Municipality, South Africa. Journal of Economics, 6(1), 37-49.

Dube, B., Roberts-Lombard, M. \& van Tonder, E. 2015. Management guidelines for universal quality challenges across the focus group research process. Journal of Applied Business Research, 31(1), 239-247.

Enslin, P. 2001. Multicultural education, gender and social justice: liberal feminist misgivings. International Journal of Educational Research, 35, 281-292.

Fenech, R., Baguant, P., Abdelwahed, I. (2019). Are you work ready? The case of Emirati women. International Journal of Entrepreneurship, 23(2), 1-10.

Gevrenova, T., 2015. Nature and Characteristics of Green Entrepreneurship. Trakia Journal of Sciences, 13(2), $321-323$.

Gibbs, D. 2009. Sustainability entrepreneurs, ecopreneurs, and the development of a sustainable economy. Greener Management International. 55, 63-78.

Glesne, C., 2011. Becoming qualitative researchers: An introduction, 4th ed., Pearson Education, Boston, MA.

Halvorsen, T, Ibsen, H \& M'kumbuzi, VRP. 2015. Knowledge for a sustainable world. A Southern-Nordic contribution. Cape Town. South Africa.

Hassan, R.A \& Nordin, R. 2016. Key Determinants of Green Entrepreneurship among SMEs in Malaysia. Proceedings of 33rd International Business Research Conference 4 - 5 January 2016, Flora Grand Hotel, Dubai, UAE.

Hechavarria, D.M., Ingram, A., Justo, R. \& Terjesen, S., 2012. Are women more likely to pursue social and environmental entrepreneurship? Global women's entrepreneurship research. Diverse settings, questions and approaches, pp.135-151.

ICS/ISSC (international Council for Science and International Social Science Council) 2015. Review of Targets for the Sustainable Development Goals: The Scientific Perspective. Paris.

Industrial Development Corporation (IDC). 2017. Economic Overview: Recent developments in the global and South African Economies. Department of Research and information. http://www.idc.co.za. Date Accessed 22 July 2019.

Irene. B.N.O. 2018. Women entrepreneurship in South Africa: Understanding the role of competencies in business success. The Southern African Journal of Entrepreneurship and Small Business Management, 9(1), a121. https://doi.org/10.4102/sajesbm.v9i1.121

Islam, Md. A., Jantan, A.M., Aldaihani, F.M.F., Rahman, Md. A., Khan, A. Md., Shahin, S., Alam, M.N. 2018. Impact of empowerment, flexibility and trust on women's access to senior positions in rmg industry of Bangladesh. International Journal of Entrepreneurship, 22(3), 1-11.

Jogee, R. \& Callaghan, C.W., 2014. A Segmentation of Mall Shopping Motivations in the South African Gauteng Provincial Context. Mediterranean Journal of Social Sciences, 5(9), 41-50.

Jonker, J., \& Pennink, B. 2010. The essence of research methodology: A concise guide for master and PhD students in management science. Springer Science \& Business Media.

Kamasturyani, Y., Sugiyo, S., Raharjo, T.J., Rifai, A. 2019. Empowering women through entrepreneurship training and courses: study in a female-dominated business. International Journal of Entrepreneurship, 23(2), 1-6.

Knight, L., Harland, C., Telgen, J., Thai, K.V., Callender, G. \& McKen, K. 2012. Public procurement: International cases and commentary. Routledge. 


\section{ENTREPRENEURSHIP AND SUSTAINABILITY ISSUES}

ISSN 2345-0282 (online) http://jssidoi.org/jesi/

2019 Volume 7 Number 2 (December)

http://doi.org/10.9770/jesi.2019.7.2(62)

Kolleck. N. 2013. How global companies wield their power: The discursive shaping of sustainable development, in J. Mikler (ed). The handbook of global companies Chichester: Wiley-Blackwell.

Kotchen, M. J. 2009. Some microeconomics of eco-entrepreneurship. In Gary D. Libecap (Eds.), Frontiers in Eco-Entrepreneurship Research (Advances in the Study of Entrepreneurship, Innovation \& Economic Growth, Volume 20) (pp. 25-37). Howard House, UK: Emerald Group Publishing Limited.

Madinga, N. W., \& Maziriri, E. T. 2018. Why do Generation Y's Share Viral Advertisements? Implications for the Sustainability of a Business. Journal of Reviews on Global Economics, 7, 000-000.

Maheshwari, M \& Sodani, P 2015. Women entrepreneurship: A literature review. Journal of Business and Management, 17(2), 6-13.

Mandipaka, F., 2014. An Investigation of the Challenges Faced by Women Entrepreneurs in Developing Countries: A Case of King Williams’ Town, South Africa. Mediterranean Journal of Social Sciences, 5(27), 1187-1193.

Manerkar, G.A. 2015. Women Entrepreneurs in Goa: Issues and Challenges. Indian Streams Research Journal, 4(12), 1-8.

Mangin 2014. How Women Entrepreneurs are contributing to the Green Economy, http://www.inclusivebusinesshub.org/profiles/blogs/how-women-entrepreneurs-are-contributing-to-the-green-economy

McEwen, T. 2013. Ecopreneurship as a Solution to Environmental Problems: Implications for College Level Entrepreneurship Education. International Journal of Academic Research in Business and Social Sciences, 3(5), 264-288

Meyer, N. 2009. An investigation into the determinants of women entrepreneurship. (Unpublished MBA-mini-dissertation.) North West University, Potchefstroom.

Meyer, S \& Hofmeyr, J. 1995. Evaluation Needs in South African Education: A Policy Perspective. Evaluation and Program Planning, 18(4), 355-363.

Mol, A. \& Spaargaren, G. 1993. Environment modernity and the risk society: The Apocalyptic horizon of environment reform. International Sociology, 8(4), 431-59.

Mol, A. P. J. 1995. The refinement of production: Ecological modernization theory and the chemical industry, Utrecht, Netherlands: Van Arkel.

Muposhi, A. 2015. Green consumer buying behaviour: Antecedents, selection attributes of generation y consumers and the relationship with future behavioural intentions. Doctor of Technology Thesis. Vaal University of Technology. Vanderbijlpark.

Muposhi, A., Dhurup, M. \& Surujlal, J. 2015. The green dilemma: Reflections of a generation y consumer cohort on green purchase behaviour. The Journal for Trans-disciplinary Research in Southern Africa, 11(3), 225-240.

Murphy, J. 2000. Ecological modernization, Geoforum, 31: 1-8.

Nxopo, Z. \& Iwu, C.G. 2015. The unique obstacles of female entrepreneurship in the tourism industry in Western Cape, South Africa. Commonwealth Youth and Development, 13(2), 55-71.

Nxopo, Z. 2014. The Role of Government in Empowering Female Entrepreneurs in the Western Cape, South Africa. Master of Technology in Business Administration (Entrepreneurship) dissertation. Cape Peninsula University of Technology, Cape Town.

O'Neill, K. and Gibbs, D. 2016. Rethinking green entrepreneurship-Fluid narratives of the green economy. Environment and Planning A, 1-10.

Pachaly, M.V.W. 2012. Barriers and Triggers to Green Entrepreneurship. Master of Science in Economics and Business Economics thesis, Erasmus University Rotterdam,

Pastakia, A., 1998. Grassroots ecopreneurs: change agents for a sustainable society. Journal of Organizational Change Management, 11(2): 157-173. 


\section{ENTREPRENEURSHIP AND SUSTAINABILITY ISSUES}

ISSN 2345-0282 (online) http://jssidoi.org/jesi/

2019 Volume 7 Number 2 (December)

http://doi.org/10.9770/jesi.2019.7.2(62)

Pinem, R. J. 2019. The role of technology in increasing motivation of millennial women entrepreneurs starting a business in the digital era. International Journal of Entrepreneurship, 23(2), 1-7.

Radebe, J.N. 2013. Draft: Transformation Policy: Vaal University of Technology.

Retief, F. J. 2009. The contribution of Appreciative Inquiry on the attitudes of church members towards a change in strategic focus. Master of business administration thesis. Management College of Southern Africa. Durban.

Roets, C. R. Q. 2013. Black generation y students' attitudes towards the de-marketing of smoking and alcohol consumption, Masters Dissertation in Marketing Management, North-West University, Vaal Triangle, Vanderbijlpark.

Roy, S., 2012. Women Entrepreneurs in Conserving Land: An Analytical Study at the Sundarbans, Bangladesh. Canadian Social Science, 8(5):125-138.

Salkind, N. J. 2012. Exploring research, Pearson, Boston, MA.

Sanyang, S.E. \& Huang, W.C. 2008. Green cooperatives: A strategic approach developing women's entrepreneurship in the Asian and Pacific region. World Journal of Agricultural Sciences, 4(6): 674-683.

Schouten, M.J. 2019. Undoing gender inequalities: insights from the Portuguese perspective. Insights into Regional Development, (2), 8598. https://doi.org/10.9770/ird.2019.1.2(1)

Senatla, M. 2011. Energy demand projections and relevance of income dynamics in Gauteng's residential sector. Journal of Energy in Southern Africa, 22(4), 31-47.

Shava, H. 2018. Impact of gender on small and medium-sized entities' access to venture capital in South Africa, South African Journal of Economic and Management Sciences 21(1), a1738. https://doi.org/10.4102/sajems.v21i1.1738

Singh, R. 2012. Women entrepreneurship issues, challenges and empowerment through self-help groups: an overview of Himachal Pradesh. International Journal of Democratic and Development Studies, 1(1):45-58.

Smith, R. 2015. Sovngjengeri mot stupet: Kapitalismens odleggelse av live tog jorda, Vardoger 35 (15): 127-149.

Sumathi, K., Anuradha, T.S. and Akash, S.B. 2014. Green Business as a Sustainable Career for Women Entrepreneurs in India: An Opinion Survey. Advances in Management, 7(5), 46-47.

Thanh, N. C., \& Thanh, T. T. 2015. The interconnection between interpretivist paradigm and qualitative methods in education. American Journal of Educational Science, 1(2), 24-27.

The Green Strategic Programme for Gauteng. 2011 . Retrieved from http://www.ecodev.gpg.gov.za/policies/.../Gauteng\%20Green\%20Strategic\%20Programme

The International Labour Organization ILO. 2016. The enabling environment for sustainable enterprises in South Africa. Geneva. http://www.ilo.org/wcmsp5/groups/public/---ed_emp/---emp_ent/---ifp_seed/documents/publication/wcms_459981.pdf

Tillery, F., \& Young, F. 2009. Sustainability entrepreneurs: Can they be the true wealth generators of the future. Greener Management International, 55, 79-92.

UN. 2013. A New Global Partnership: Eradicate Poverty and Transform Economies Through Sustainable Development. Report of the High-Level Panel of Eminent Persons on the Post-2015 Development Agenda. Available online.

UN. 2015. Global Sustainable Development Report 2015 (Advance unedited edition). New York.

United Nations Environment Programme (UNEP). 2011. Green Economy, http://www.unep.org/greeneconomy/,e.t:01.03.2015 


\section{ENTREPRENEURSHIP AND SUSTAINABILITY ISSUES}

ISSN 2345-0282 (online) http://jssidoi.org/jesi/

2019 Volume 7 Number 2 (December)

http://doi.org/10.9770/jesi.2019.7.2(62)

United Nations Environment Programme (UNEP). 2011. Retrieved from http://www.un.org/esa/socdev/unpfii/documents/2015/agenciesinfo/UNEP.pdf

Uslu, Y.D., Hancıŏlu, Y. and Demir, E., 2015. Applicability to green entrepreneurship in Turkey: A situation analysis. Procedia-Social and Behavioral Sciences, 195, 1238-1245.

Van Der Merwe, M. 2008. A study of discrimination against women entrepreneurs when applying for financial assistance. Phil thesis, University of Pretoria: Pretoria

Wahyuni, D. 2012. The research design maze: Understanding paradigms, cases, methods and methodologies. Journal of Applied Management Accounting Research, 10(1), 69-80.

Welman, C., Kruger, F. \& Mitchell, B. 2011. Research methodology, 3rd ed, Oxford University Press, Cape Town.

Wilson, J. 2010. Essentials of Business Research. A guide to doing your research project. Great Britain: Sage Publications.

World Bank. 2017. Women Entrepreneurs Finance Initiative. http://www.worldbank.org/en/programs/women-entrepreneurs

Xaba, G. M. \& Rankhumise, E. M. 2014. Business owners' perspectives in pursuance of their businesses: what matters most? Problems and perspectives in management, 12(2), 181-189.

Xavier, S.R., Ahmad, S.Z., Nor, L.M. and Yusof, M., 2012. Women entrepreneurs: Making a change from employment to small and medium business ownership. Procedia Economics and Finance, 4, 321-334.

Yenilmez, M.I. 2018. An inquiry into improving women participation in entrepreneurship in Turkey. International Journal of Entrepreneurship, 22(3), 1-15.

York, R., \& Rosa, E.A. 2003. Key Challenges to Ecological Modernization Theory, Organization \& Environment, 16(3): $273-288$.

\section{Acknowledgements}

This research was supported by the Govan Mbeki Research Development Centre at the University of Fort Hare in South Africa. 


\section{ENTREPRENEURSHIP AND SUSTAINABILITY ISSUES}

ISSN 2345-0282 (online) http://jssidoi.org/jesi/

2019 Volume 7 Number 2 (December)

http://doi.org/10.9770/jesi.2019.7.2(62)

Dr. Eugine TAFADZWA MAZIRIRI holds a PhD in Business Sciences (Marketing) from University of the Witwatersrand, Johannesburg, South Africa. He has keen interest in entrepreneurial marketing and entrepreneurship research, specifically green marketing in small businesses and green entrepreneurship. He has published numerous papers in peer reviewed internationally accredited journals. He has presented and participated in local and international conferences. Research is his passion as he has always learned a lot from it as well as disseminating knowledge to others.

ORCID ID: http://orcid.org/0000-0002-8047-4702

Dr. Miston MAPURANGA is a holder of $\mathrm{PhD}$ in Management of Technology and Innovation from Davinci Institute, a School of Business Leadership. He is researcher who is interested in agribusiness, entrepreneurship and finance. He has published in peer reviewed internationally accredited journals.

ORCID ID: https://orcid.org/0000-0002-4402-5600

Dr. Tafadzwa CLEMENTINE MARAMURA is a PhD holder from the University of North West, South Africa. She is a double valedictorian, who holds a Bachelor of Social Science (Cum Laude), Honours Public Policy (Cum Laude), and a Master of Public Policy (Governance) from the University Of Fort Hare in South Africa. She has published in various peerreviewed high impact journals and is currently doing her Post-Doctoral research fellowship at the University Of Fort Hare.

ORCID ID: https://orcid.org/0000-0002-4419-1887

Prof. Ogochukwu IRUOMA NZEWI is a PhD holder from the University of Pretoria in South Africa and she is a well renowned academic. She is currently the Head of Department of the Public Administration Department at the University of Fort Hare in South Africa.

ORCID ID: https://orcid.org/0000-0002-2377-0855

Register for an ORCID ID:

https://orcid.org/register

Copyright (C) 2019 by author(s) and VsI Entrepreneurship and Sustainability Center

This work is licensed under the Creative Commons Attribution International License (CC BY).

http://creativecommons.org/licenses/by/4.0/

cC) (†) Open Access 